Prepared in cooperation with the

Pennsylvania Department of Conservation and Natural Resources, Bureau of Topographic and Geologic Survey

\title{
Drilling and Geophysical Logs of the Tophole at an Oil- and- Gas Well Site, Central Venango County, Pennsylvania
}

\section{Abstract}

In a study conducted by the U.S. Geological Survey, in cooperation with the Pennsylvania Department of Conservation and Natural Resources, Bureau of Topographic and Geologic Survey, drilling and geophysical logs were used to characterize the geohydrologic framework and the freshwater and salinewater zones penetrated by the tophole at an oil-and-gas well site in central Venango County, Pennsylvania. The geohydrologic setting of the well site is typical of the dissected Appalachian
Plateau underlain by Pennsylvanian and Mississippian sandstone and shale. The drilling, gamma, and acoustic-televiewer logs collected from the 575-foot deep tophole define the penetrated Pennsylvanian and Mississippian stratigraphic units and their lithology. The caliper, video, and acoustic-televiewer logs delineate multiple bedding-related and high-angle fractures in the lower Pottsville Group and Shenango Formation from 22 to 249 feet below land surface. The caliper and acoustic-televiewer logs indicate a sparsity of fractures below 249 feet below land surface in the lowermost Shenango Formation, Cuyahoga
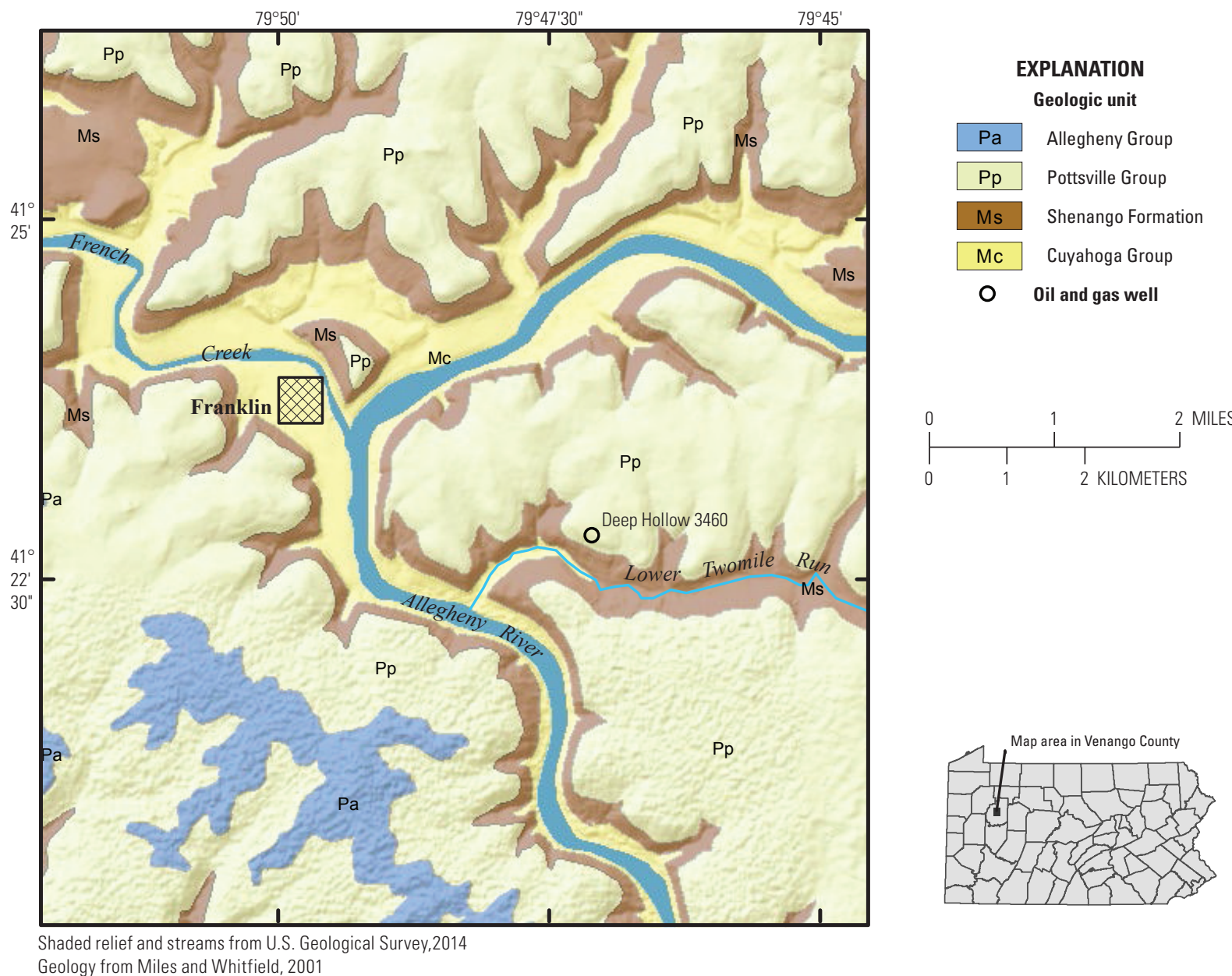

Figure 1. Bedrock geology and location of the Deep Hollow 3460 oil-and-gas well site, central Venango County, Pennsylvania. 
Group, Corry Sandstone, "Drake Well” formation, and upper Riceville Formation.

About half of the blown yield during drilling of the tophole was from fractures in the upper Shenango Formation between 80 and 167 feet below land surface and the other half from fractures in the lower Shenango between 190 and 249 feet below land surface. Following drilling, fractures above the water level at about 145 feet below land surface produced freshwater with a specific conductance of less than 150 microsiemens per centimeter at 25 degrees Celsius that cascaded down the hole. As indicated by the fluid resistivity and temperature logs, most of the downflow exited the hole at the water-bearing fractures at 249 feet below land surface. The downward flow in the tophole reflects the downward hydraulic gradient between the waterbearing fractures above the water level and those at 249 feet below land surface.

Low conductivity and high resistivity values on the dual induction logs indicate freshwater above 285 feet below land surface in the Shenango sandstones, which is consistent with a specific conductance of blown yield of 400 microsiemens per centimeter at 25 degrees Celsius at 200 feet below land surface. High conductivity and low resistivity values on the induction logs indicate the presence of saline water below 450 feet in the Corry Sandstone. The highest specific conductance of the blown yield, 1,200 microsiemens per centimeter at 25 degrees Celsius, was measured at 480 feet below land surface following penetration of the Corry Sandstone.

Collection and integrated analysis of drilling and geophysical logs provided an efficient and effective means for characterizing the geohydrologic framework and conditions penetrated by the tophole at the selected oil-and-gas well site. The logging methods and lessons learned at this well site could be applied at other oil-and-gas drilling sites to better characterize the shallow subsurface with the overall goal of protecting freshwater aquifers during hydrocarbon development.

\section{Introduction}

Although geophysical logs are extensively used by the petroleum industry to characterize the subsurface, the upper part of the hole or tophole of oil-and-gas wells historically has not been logged. Information on the shallow distribution of bedrock lithology, fractures, freshwater and saline-water zones, and gas zones is critical for the proper design and installation of the surface casing and cement that protects drinking-water aquifers. The U.S. Geological Survey, in cooperation with the Pennsylvania Department of Conservation and Natural Resources, Bureau of Topographic and Geologic Survey, collected and analyzed drilling and geophysical logs to evaluate their use in characterizing the geohydrologic framework and occurrence of freshwater and saline water penetrated by the tophole interval of an oil-and-gas well.

\section{Description of Well Site}

The Deep Hollow 3460 oil-and-gas well site is located about 1 mile southeast of the City of Franklin in central Venango County, Pennsylvania (fig. 1). The site is part of an oil-gas well field that is being developed with a series of hydraulically fractured vertical wells in the Venango Formation. The geohydrologic setting of the well site is typical of the dissected Appalachian Plateau as described by Poth (1963) and Wyrick and Borchers (1981). The site, which is at an altitude of 1,368 feet (ft) above NAVD 88, is on a steep, wooded, south-facing slope of a broad-topped upland that is dissected by Lower Twomile Run to the south and the Allegheny River to the west and north. Topographic relief in the area is more than $400 \mathrm{ft}$. Resistant sandstone of the Pennsylvanian Pottsville Group caps the upland, sandstone and shale of the Mississippian Shenango Formation outcrop on the slope above Lower Twomile Run, and shale of the Mississippian Cuyahoga Group underlies the valley bottom of Lower Twomile Run.

\section{Drilling Log}

The tophole at the Deep Hollow 3460 oil-and-gas well was drilled with an Ingersoll Rand T-4 air-hammer rig and attached auxiliary air compressor (fig. 2). On March 5, 2014, a 10 3/4-inch nominal hole was drilled from land surface to 21 feet below land surface (ft bls), and a 9-inch-diameter casing was set to that depth. The next day, a 8 3/4-inch nominal diameter hole was drilled from 21 to $575 \mathrm{ft}$ bls. During drilling of the tophole below the casing, penetration rates, fractured intervals as indicated by drill-bit jumps and drops, and changes in the texture and color of drill cuttings were noted. The plan was to measure the air-blown water yield as drilling progressed using timed volumetric and (or) weir measurements. However, this was not possible because the end of the blown-discharge pipe was in the middle of the lined mud pit, which was excavated into the side of the hillslope. Therefore, the blown water yields were estimated by eye and are approximations. Consequently, small increases in blown yield relative to the total blown yield were not detected. Water samples of the air-blown yield were collected at the pipe discharge point with an open container attached to a 6 - $\mathrm{ft}$ long pole, following detected increases in the

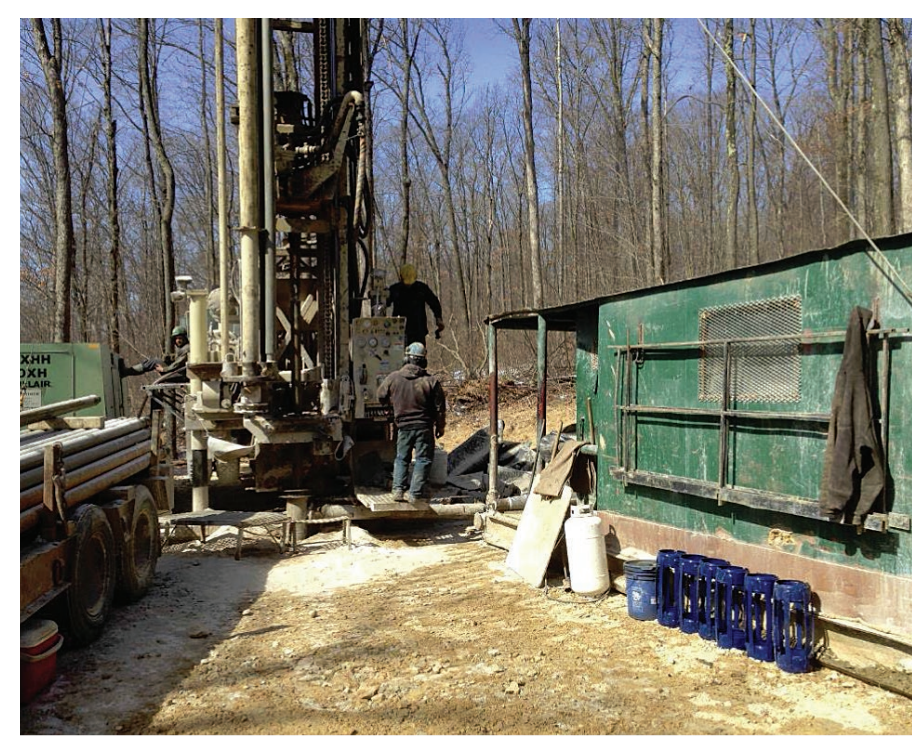

Figure 2. Air-hammer drilling rig, auxiliary air compressor, and drill rod during drilling of the tophole at the Deep Hollow 3460 oil-andgas well site, central Venango County, Pennsylvania, March 6, 2014. 
yield. The water samples were analyzed onsite for combustible gas, temperature, and specific conductance. No combustible gas was detected in the water samples.

The drilling log of the tophole notes (1) white sandstone cuttings and fractured at $55 \mathrm{ft}$ bls, (2) first blown-water yield with a specific conductance of less 150 microsiemens per centimeter $(\mu \mathrm{S} / \mathrm{cm})$ at 25 degrees Celsius $\left({ }^{\circ} \mathrm{C}\right)$ at $75-80 \mathrm{ft} \mathrm{bls}$, (3) brown sandstone cuttings and fractured at 150-155 ft bls, (4) estimated total blown water yield of 10 gallons per minute (gal/min) at $180 \mathrm{ft} \mathrm{bls,} \mathrm{(5)} \mathrm{fractured} \mathrm{at} 190 \mathrm{ft} \mathrm{bls,} \mathrm{(6)} \mathrm{total} \mathrm{blown}$ yield of $20 \mathrm{gal} / \mathrm{min}$ with specific conductance of $400 \mu \mathrm{S} / \mathrm{cm}$ at $25^{\circ} \mathrm{C}$ at $205 \mathrm{ft}$ bls, (7) fractured at 235-240, 270, and $281 \mathrm{ft}$ bls, (8) light to dark gray cuttings and no observed change in estimated total blown yields at 305, 340, and $430 \mathrm{ft}$ bls, (9) estimated total blown yield of $20+\mathrm{gal} / \mathrm{min}$ with specific conductance of $1,200 \mu \mathrm{S} / \mathrm{cm}$ at $25^{\circ} \mathrm{C}$ at $480 \mathrm{ft}$ bls, and (10) estimated total blown yield of 20 to $25 \mathrm{gal} / \mathrm{min}$ with specific conductance of $950 \mu \mathrm{S} / \mathrm{cm}$ at $25^{\circ} \mathrm{C}$ at total depth (fig. 3).

The tophole was drilled to total depth of $575 \mathrm{ft}$ bls in about 6 hours. The average drilling rate was 1.8 feet per minute (ft/min) or 14 minutes per $25-\mathrm{ft}$ drill rod. After reaching total depth, the drill rods and air hammer were removed from the hole. The tophole was not developed with the air-hammer rig and compressed air to produce clear water discharge as is typically done for water-supply wells. The depth of water level when initially measured was $190 \mathrm{ft}$ bls. The water level had not stabilized and was recovering at a rate of $3 \mathrm{ft} / \mathrm{min}$, which corresponds to an inflow rate of about $9 \mathrm{gal} / \mathrm{min}$. The sound of water cascading into the hole from above the water level was heard. After 3 hours, the water level had recovered to about $145 \mathrm{ft}$ bls and appeared close to being stabilized. The sound of water cascading into the hole continued.

\section{Geophysical Logs}

Gamma, caliper, acoustic-televiewer (ATV) and deviation, video, fluid resistivity and temperature, and dual induction logs were collected from the tophole at the Deep Hollow 3460 oil-and-gas well site. Geophysical log collection began within $1 / 2$ hour of tophole completion. The geophysical logs were collected in 4 hours, with the video and ATV logs taking about one-half of the time. Geophysical logs and their application in geohydrologic investigations are described in Kelley (1969), Keys (1990), and Rider and Kennedy (2011).

\section{Gamma Log}

The gamma log recorded the amount of gamma radiation emitted by the formation surrounding the hole. Naturally occurring sources of gamma radiation include potassium-40 and daughter products of the uranium- and thorium-decay series. Clay-bearing rocks commonly emit relatively high gamma radiation because they include weathering products of potassium feldspar and mica and tend to concentrate uranium and thorium by ion absorption and exchange. The gamma log was used to delineate the stratigraphic units and lithology penetrated by the tophole.

The gamma log interpreted along with the drilling log indicates that the tophole penetrated sandstone and shale of
Pennsylvanian and Mississippian age. The stratigraphic units identified on the gamma log (C.H. Dodge, Pennsylvania Department of Conservation and Natural Resources, Bureau of Topographic and Geologic Survey, written commun., 2014), in descending order, are the lower Pottsville Goup, Shenango Formation, Cuyahoga Group, Corry Sandstone, "Drake Well" formation (informal), and upper Riceville Formation (fig. 3). The lower Pottsville Group was penetrated from 21 to $81 \mathrm{ft} \mathrm{bls}$ and consists of white sandstone with some shale. The gamma $\log$ indicates intervals of sandstone from 27 to $41 \mathrm{ft}$ bls and 71 to $81 \mathrm{ft}$ bls. The Shenango Formation was penetrated from 81 to $287 \mathrm{ft}$ bls and consists of interbedded brown sandstone and shale. The gamma log indicates intervals of sandstone from 116 to 124,140 to 189,220 to 229,249 to 260 , and 265 to $287 \mathrm{ft}$ bls. The Cuyahoga Group was penetrated from 287 to $450 \mathrm{ft}$ bls and consists mostly of gray shale. A sandstone bed was penetrated from 444 to $449 \mathrm{ft}$ bls in this shale-rich unit. The Corry Sandstone was penetrated from 450 to $470 \mathrm{ft}$ bls and consists of sandstone with a shale bed from 459 to $461 \mathrm{ft}$ bls. The "Drake Well" formation was penetrated from 470 to $540 \mathrm{ft}$ bls and consists of shale with some thin sandstone beds. The upper Riceville Formation was penetrated from 540 to $575 \mathrm{ft}$ bls and consists mostly of shale.

\section{Caliper Log}

The caliper log, which recorded the diameter of the hole, was collected with a probe equipped with three spring-loaded arms. A three-arm caliper is more sensitive to changes in hole diameter than the single-arm caliper typically used in the oiland-gas industry. Changes in hole diameter were correlated with fractures and competency of lithologic units.

The caliper log displayed hole enlargements, indicating fractured intervals from 22 to 57, 80 to 140,190 to 204, 213 to 220 , and 247 to $249 \mathrm{ft}$ bls (fig. 3). Only minor hole enlargements were recorded below $249 \mathrm{ft}$, suggesting a sparsity of fractures in the bottom half of the tophole.

\section{Acoustic-Televiewer and Deviation Logs}

The acoustic-televiewer (ATV) log recorded a 360-degree magnetically oriented acoustic-reflection image of the hole wall. The ATV log was collected in the turbid, water-filled interval from 144 to $572 \mathrm{ft}$ bls. The ATV log provided high-resolution information on hole-wall reflectivity related to lithology and the depth and orientation of planar structural features, including bedding and fractures. The deviation log recorded the vertical deviation and spatial trajectory of the tophole with two inclinometers and a three-component magnetometer housed in the ATV probe. The deviation logs were used to correct the apparent orientation of structural features identified on the ATV logs to their true orientation. Deviation of the tophole was less than 1 degree from vertical.

Competent intervals of sandstone appear as relatively uniform zones of strong acoustic reflectivity. Shale intervals were identified by their more variable and weaker acoustic reflectivity. Bedding features are best defined in the interbedded shale and sandstone intervals. Bedding features within thicker shale or sandstone intervals are not well defined. Average dip of 


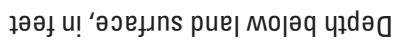
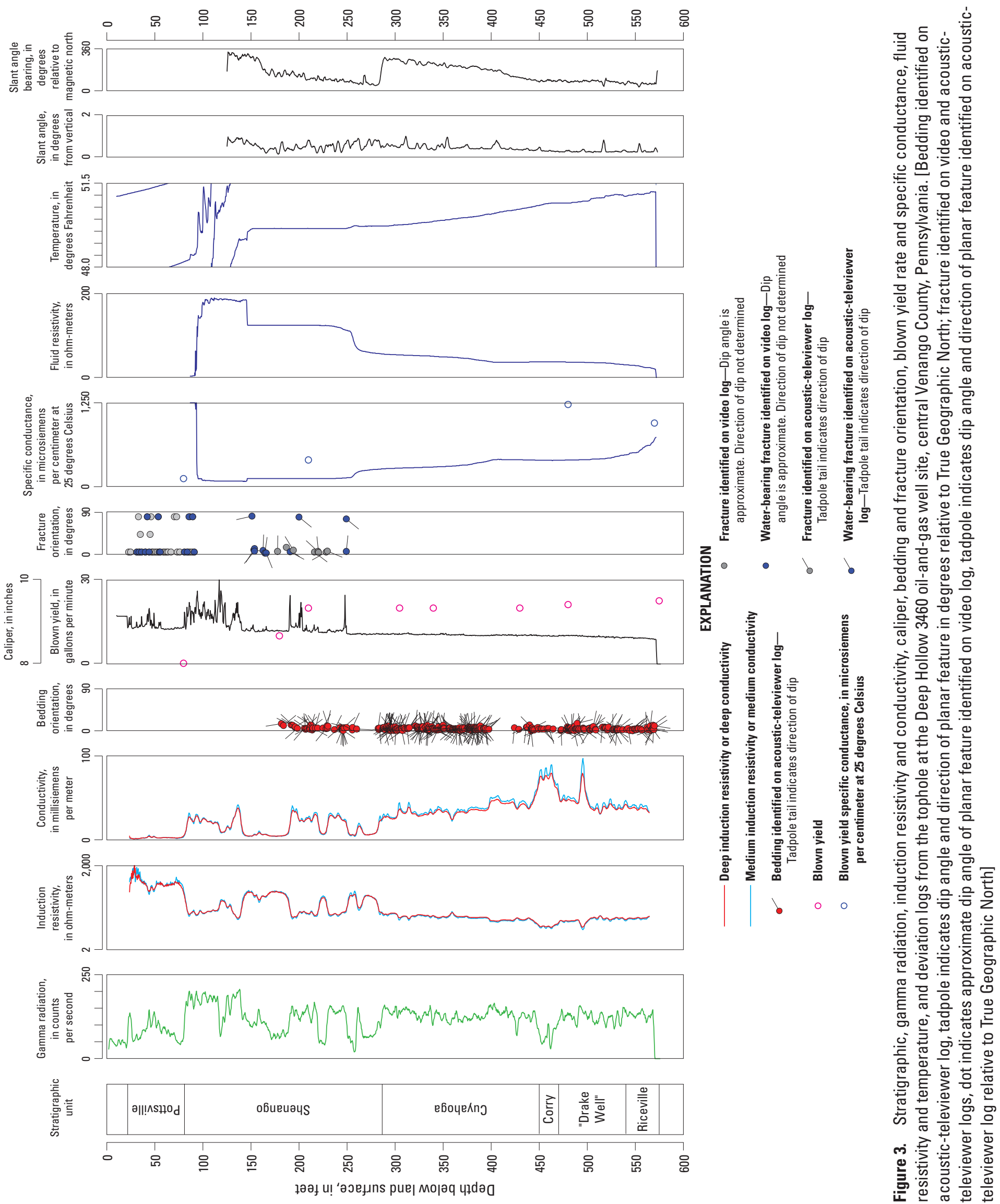
the bedding is 4.5 degrees, and dip direction is highly variable. Bedding-related and high-angle fractures are delineated on the ATV log. Fractures that are bedding related have an average dip of 6.5 degrees. High-angle fractures have an average dip of 79 degrees. Bedding-related fractures are present at 152, 162-166, 190, 208, 216, 220, and $249 \mathrm{ft}$ bls (fig. 4). High-angle fractures are present at 152, 201, and $249 \mathrm{ft}$ bls. Consistent with the caliper log, the ATV log indicates a sparsity of fractures in the bottom half of the tophole.

\section{Video Log}

The video log, which recorded moving images of the tophole, was collected with a waterproof, depth-encoded, color video camera. Video images were obtained through a wideangle lens and recorded on a DVD/DVR recorder. The video log was collected in the tophole from 3 to $301 \mathrm{ft}$ bls. The bottom of shallow casing was observed at $21.3 \mathrm{ft}$ bls. The water level at the time of the video log was $151.2 \mathrm{ft}$ bls and appeared to be rising. Below the water level, the water was turbid, and the hole wall was not visible, although scattered light was returned. Light returns continued to decrease until $300 \mathrm{ft}$ bls, where the video log became completely dark.

Changes in hole-wall roughness, color, and other features, indicating likely lithologic contacts, were observed on the video $\log$ at 71, 72, 74, 81, 86, 88, 98, and $104 \mathrm{ft}$ bls. Numerous bedding-related fractures and high-angle fractures were observed between 22 and $104 \mathrm{ft}$ bls (fig. 3). Some dampness was observed below the bedding-related fractures at 31-32, 34, 36-37, 40, 44-45, 54-56, and 81-85 ft bls. Bedding-related fractures at 89,94 , and 104 were iron-oxide stained, indicating they are likely water bearing. High-angle fractures were observed at $33,42,46,48,54,71,86,87,90,94,97$, and $101 \mathrm{ft}$ bls. Some dampness was observed below the high-angle fractures at 42 and $54 \mathrm{ft}$ bls. The most prominent of the highangle fractures are at 90 and $97 \mathrm{ft}$ bls. The 90 - $\mathrm{ft}$ deep fracture was stained with an iron-oxide coating, and water was visible cascading from the fracture (fig. 5). Additional cascading water from fractures below $90 \mathrm{ft}$ bls was observed, but the exact depths of cascading water could not be determined because the cascading water coming from the zones above obscured the view of the camera. At $107 \mathrm{ft}$ bls, the hole wall was no longer observable because of the large amount of water cascading down around the camera.

\section{Fluid Resistivity and Temperature Logs}

The fluid resistivity log recorded the electrical resistivity of the water column in the tophole. The electrical resistivity of the water is related to its dissolved-solids concentration. The specific conductance logs were calculated from the fluid resistivity and the temperature logs. The temperature log recorded the temperature of the air and water column in the tophole. Where the temperature-log gradient approaches the geothermal gradient, typically about 0.6 degree Celsius $\left({ }^{\circ} \mathrm{C}\right)$ per $100 \mathrm{ft}$ (Keys, 1990), the water column is in equilibrium with the surrounding rocks, indicating the presence of little or no vertical flow in the hole interval. Where the temperature-log gradient approaches an isothermal gradient, the water column is not in equilibrium with the surrounding rocks, indicating the presence of significant vertical flow in the hole interval. The fluid resistivity, specific
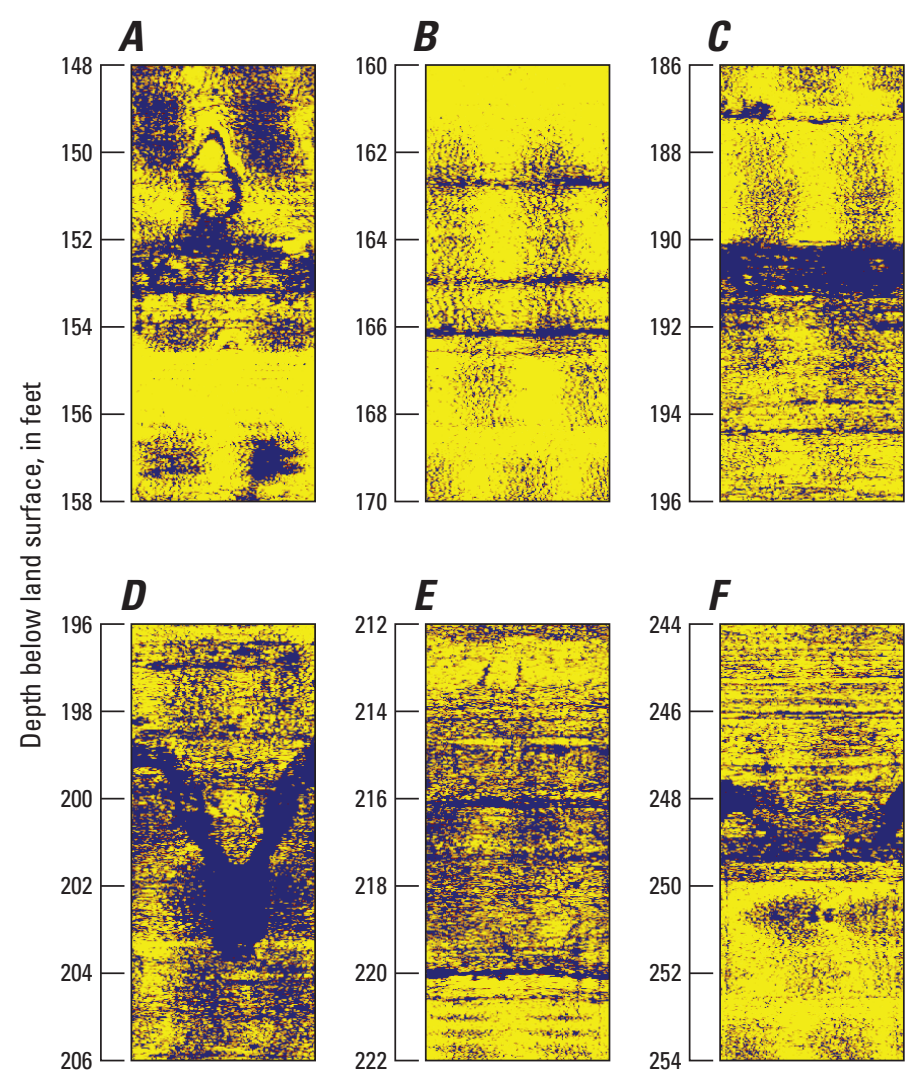

Figure 4. Acoustic-televiewer images of the tophole at the Deep Hollow 3460 oil-and-gas well site, central Venango County, Pennsylvania: $A$, bedding-related and high-angle fractures penetrated at 152 feet below land surface (ft bls), B, beddingrelated fractures penetrated at 162 to $166 \mathrm{ft}$ bls, C, bedding-related fracture penetrated at $190 \mathrm{ft} \mathrm{bls,} \mathrm{D,} \mathrm{high-angle} \mathrm{fracture} \mathrm{penetrated}$ at $201 \mathrm{ft} \mathrm{bls,} \mathrm{E,} \mathrm{bedding-related} \mathrm{fractures} \mathrm{penetrated} \mathrm{at} 216$ and 220 $\mathrm{ft} \mathrm{bls}$, and $\mathrm{F}$, bedding-related and high-angle fractures penetrated at $249 \mathrm{ft}$ bls.

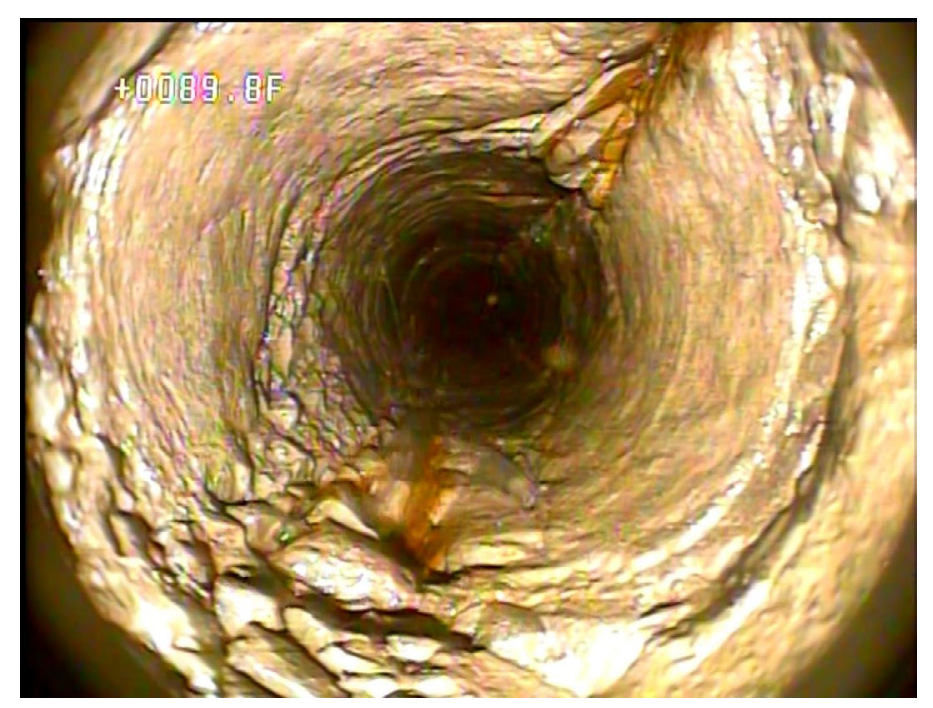

Figure 5. Video image of cascading water from an iron-stained, high-angle fracture penetrated at 90 feet below land surface in the tophole at the Deep Hollow 3460 oil-and-gas well site, central Venango County, Pennsylvania. 
conductance, and temperature logs were used to identify flow zones and possible flow between them.

The fluid resistivity, specific conductance, and temperature logs indicate cascading water with specific conductance less than $150 \mu \mathrm{S} / \mathrm{cm}$ at $25^{\circ} \mathrm{C}$ from water-bearing fractures between 80 and $138 \mathrm{ft}$ bls (fig. 3). Below the water level at about $145 \mathrm{ft}$ bls and above the water-bearing fractures at $249 \mathrm{ft}$ bls, the fluid resistivity, specific conductance, and temperature of the downflow were relatively constant, indicating that there is little or no change in the downward flow. The isothermal temperature gradient, the nearly constant values recorded by the specific conductance log, and the rapidity in which these conditions were established, indicate a substantial amount of downward flow in this interval that is consistent with conditions observed on the video log above the water level. Some outflow of water to the water-bearing fractures at 190 to $216 \mathrm{ft}$ bls may have occurred but not enough to affect the temperature-log gradient. The slope changes in the fluid resistivity and temperature logs indicate that most of the downflow exited the hole at the waterbearing fractures at $249 \mathrm{ft}$ bls.

The temperature-log gradient below the 249-ft waterbearing fractures generally was about $0.3{ }^{\circ} \mathrm{C}$ per $100 \mathrm{ft}$ (fig. 3). Although this gradient is less than the geothermal gradient, it does not necessarily indicate the presence of vertical flow in the lower half of the tophole as there was less than 3 hours elapsed time for the water to reach equilibrium with the surrounding bedrock following the cessation of drilling. The temperature log displays changes in slope at 465, 502, and $538 \mathrm{ft}$ bls within the Corry Sandstone and "Drake Well" formation interval. The specific conductance logs display a sharp change in slope at $404 \mathrm{ft}$ bls within the Cuyahoga Group interval and higher specific conductance below this depth. The specific conductance $\log$ also indicates increasing total dissolved solids in the water in the bottom $50 \mathrm{ft}$ of the hole. It is not known whether these changes in the temperature and specific conductance logs relate to small changes in flow associated with undetected fractures or are remnants of the drilling operation.

\section{Dual Induction Logs}

Dual induction logs measured the electrical conductivity of rocks and water surrounding the tophole. The dual-induction tool, which operates at a frequency of about 100 kilohertz, has intercoil spacings of 50 and 80 centimeters to provide medium and deep focused measurements of electrical conductivity. Electrical conductivity measurements are affected by the clay content and porosity of the rocks and by the dissolved-solids concentration of the pore fluid. An induction-resistivity log was calculated from the induction-conductivity log. The inductionconductivity and -resistivity logs were interpreted along with the gamma log to delineate sandstones with freshwater-filled porosity and sandstones with saline-water-filled porosity.

Shale intervals show a minimal range in induction conductivity and resistivity values, whereas values in sandstone intervals varied with depth, reflecting the increase in the salinity of the pore water (figs. 3 and 6). Above $283 \mathrm{ft}$ bls, induction conductivity and gamma radiation were positively correlated reflecting air- and freshwater-filled porosity. Sandstones with air-filled porosity in the Pottsville Formation from 21 to 81

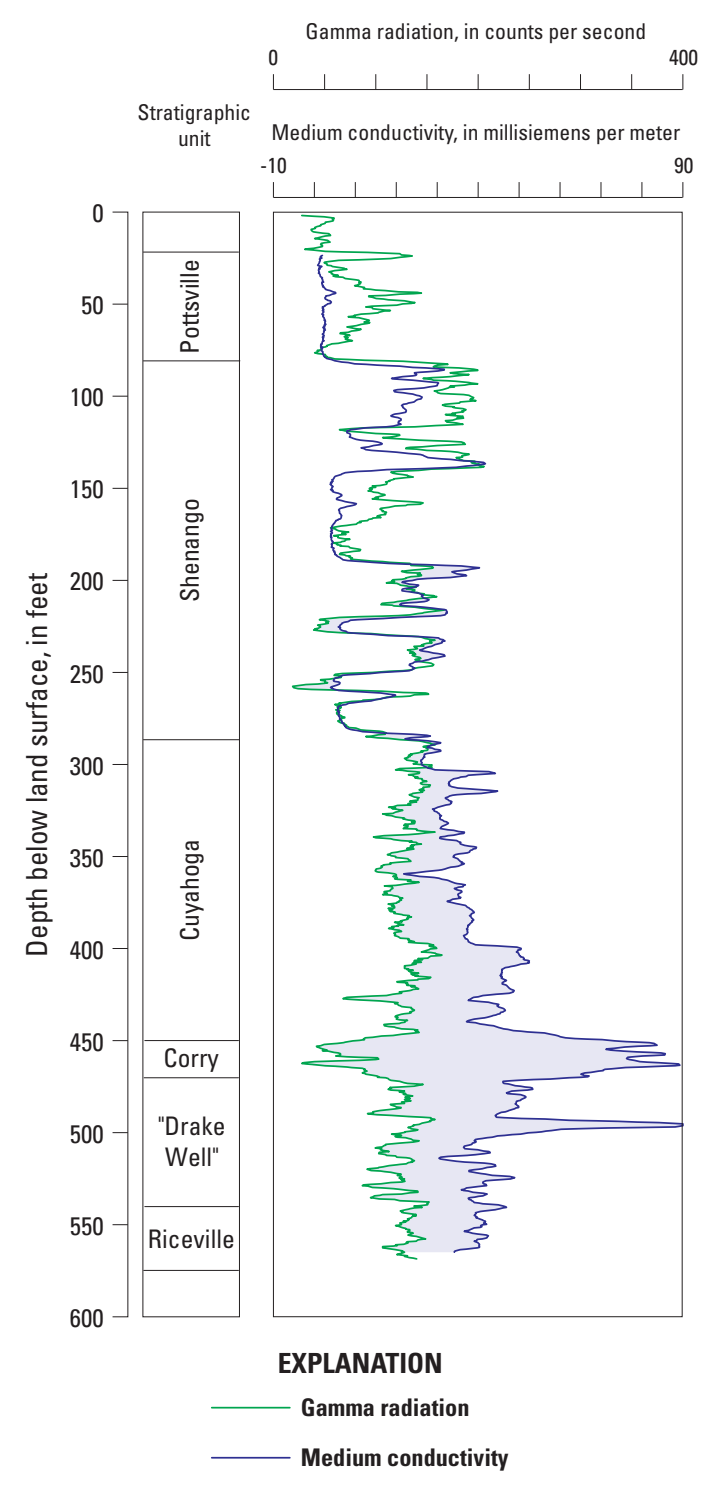

Figure 6. Stratigraphic, gamma, and medium induction conductivity logs from the tophole at the Deep Hollow 3460 oil-and-gas well site, central Venango County, Pennsylvania.

$\mathrm{ft}$ bls had the lowest induction conductivity and highest induction resistivity. The Shenango Formation between 142 and 283 $\mathrm{ft}$ bls also had low induction conductivity and high induction resistivity, indicating the presence of freshwater in the sandstones. This is consistent with the specific conductance of the blown yield during drilling, which was $400 \mu \mathrm{S} / \mathrm{cm}$ at $200 \mathrm{ft}$ bls.

In the Cuyahoga Group from 287 to $450 \mathrm{ft}$ bls, induction conductivity values generally increased and induction resistivity values generally decreased with depth (figs. 3 and 6). In the middle and lower Cuyahoga Group, sandstone beds from 356 to 361 and 424 to $429 \mathrm{ft}$ bls had lower conductivity and higher resistivity than surrounding shales, but the difference was less than in the Shenango Formation, reflecting increased clay content and (or) increased pore-water dissolved-solids content in the Cuyahoga sandstones compared to those in the Shenango Formation. 
Below $450 \mathrm{ft}$ bls, induction conductivity and gamma radiation were negatively correlated, reflecting saline-water-filled porosity in the sandstones. In the Corry Sandstone from 450 to $470 \mathrm{ft}$, high induction conductivity and low induction resistivity indicate the presence of saline water (fig. 3 and 6). The highest specific conductance of the blown yield, $1,200 \mu \mathrm{S} / \mathrm{cm}$ at $25^{\circ} \mathrm{C}$, was measured at $480 \mathrm{ft}$ bls following penetration of the Corry Sandstone. High induction conductivity and low induction resistivity at $496 \mathrm{ft}$ bls in the "Drake Well" formation indicate the presence of a zone of saline-water-filled porosity that appears to be associated with a thin sandstone bed delineated on the ATV $\log$.

\section{Discussion of Logging Results}

Collection of drilling and geophysical logs and their integrated analysis provided an efficient and effective means for characterizing the geohydrologic framework and conditions penetrated by the tophole at the selected oil-and-gas well site. Log-data collection for the study caused minimal disruption of the normal drilling operations. As discussed below, the lessons learned during this effort could be used to help improve future log-data collection and interpretation at oil-and-gas drilling sites.

The arrangement of the drill rig, compressor, drill rods, driller shelter, waste tanker truck, cuttings pit, and discharge pipe at the Deep Hollow 3460 oil-and-gas well site was less than ideal for the collection of blown yield discharge measurements, drill cuttings, and water samples. Although there are limitations to what can be done given the relatively small work area and the large amount of equipment, some rearrangement may be possible to provide better access without affecting the drilling operation. Given that relatively small increases in blown yield from the tophole were not detected and that they appear to have a significant effect on the specific conductance of the discharge water, it would have been prudent to collect water samples at regular depth intervals such as each time drilling was resumed following drill-rod change, which would correspond to every $25 \mathrm{ft}$.

The video logs were useful for geohydrologic characterization of the tophole above the water level. However, owing to the turbidity of the water, no information was gained from the video log below the water level. The tophole would need to be developed to produce clear water as is typically done following the drilling of water-supply wells. Significant improvement in water clarity would not be expected even if more time was allowed without developing the tophole. Development of the tophole with compressed air until the discharge is clear as is done for water-supply wells may take several hours. Considering the rig and crew costs and tight schedules associated with oil-and-gas drilling, it is not likely that this will become part of the routine operation.

The fluid resistivity and temperature logs of tophole intervals that had substantial vertical flow between fractures stabilized quickly after drilling, and interpretation of the logs was straightforward and provided solid information. However, the fluid resistivity and temperature logs of tophole intervals that had little or no vertical flow between fractures were significantly affected by drilling, did not stabilize, and could not be interpreted with any confidence. Collection of additional fluid logs after the water column has longer to stabilize would be desirable. If drilling is done on a regular day-shift schedule, it would be possible to let the hole sit overnight and relog fluid resistivity and temperature very early the next morning prior to the start of drilling. This would allow time for the water column in intervals of little or no flow to better stabilize with the geothermal temperature, and small discharges from saline-water seeps to cause spikes of elevated dissolved solids, as has been documented in a deep open corehole in north-central Pennsylvania (Risser and others, 2013).

\section{Summary}

This study was conducted by the U.S. Geological Survey in cooperation with the Pennsylvania Department of Conservation and Natural Resources, Bureau of Topographic and Geologic Survey. Drilling, gamma, caliper, acoustic-televiewer (ATV) and deviation, video, fluid resistivity and temperature, and dual induction logs were used to characterize the geohydrologic framework and the freshwater and saline-water zones penetrated by the tophole at the Deep Hollow 3460 oil-andgas well site in central Venango County, Pennsylvania. The drilling, gamma, and ATV logs define the penetrated sandstone and shale lithologies and Pennsylvanian and Mississippian stratigraphic units. The caliper, video, and ATV logs delineate multiple bedding-related and high-angle fractures in the lower Pottsville Group and Shenango Formation from 22 to 249 feet below land surface (ft bls). The caliper and ATV logs indicate a sparsity of fractures deeper than $249 \mathrm{ft}$ bls in the lowermost Shenango Formation, Cuyahoga Group, Corry Sandstone, "Drake Well" formation, and upper Riceville Formation.

Estimated blown yield from the tophole at total depth of $575 \mathrm{ft}$ bls is 20 to 25 gallons per minute (gal/min). About half of this blown yield is from fractures in the upper Shenango Formation between 80 and $167 \mathrm{ft}$ bls and the other half from fractures in the lower Shenango between 190 and $249 \mathrm{ft}$ bls. Following drilling, fractures above the water level at about $145 \mathrm{ft}$ bls produced freshwater with a specific conductance of less than 150 microsiemens per centimeter $(\mu \mathrm{S} / \mathrm{cm})$ at 25 degrees Celsius $\left({ }^{\circ} \mathrm{C}\right)$ that cascaded down the hole. As indicated by the fluid resistivity and temperature logs, most of the downflow exited the hole at the water-bearing fractures at $249 \mathrm{ft}$ bls. Some of the water may have exited the hole at fractures between 190 and $216 \mathrm{ft}$ bls. The downward flow in the tophole reflects the downward hydraulic gradient between the water-bearing fractures above the water level and those at $249 \mathrm{ft}$ bls.

Low conductivity and high resistivity values on the dual induction logs indicate freshwater above $285 \mathrm{ft}$ bls in the Shenango sandstones, which is consistent with a specific conductance of blown yield of $400 \mu \mathrm{S} / \mathrm{cm}$ at $25^{\circ} \mathrm{C}$ at $200 \mathrm{ft}$ bls. High conductivity and low resistivity values on the induction logs indicate the presence of saline water below $450 \mathrm{ft}$ in the Corry Sandstone. The highest specific conductance of the blown yield, $1,200 \mu \mathrm{S} / \mathrm{cm}$ at $25^{\circ} \mathrm{C}$, was measured at $480 \mathrm{ft}$ bls following penetration of the Corry Sandstone. 
Collection and integrated analysis of drilling and geophysical logs provided an efficient and effective means for characterizing the geohydrologic framework and conditions penetrated by the tophole at the selected oil-and-gas well site. The logging methods and lessons learned at this well site could be applied at other oil-and-gas drilling sites to better characterize the shallow subsurface with the overall goal of protecting freshwater aquifers during hydrocarbon development.

—By John H. Williams, Philip H. Bird, Randall W. Conger, and J. Alton Anderson

\section{References Cited}

Kelley, D.R., 1969, A summary of major geophysical logging methods: Pennsylvania Geological Survey, 4th ser., Mineral Resources Report 61, 82 p.

Keys, W.S., 1990, Borehole geophysics applied to ground-water investigations: U.S. Geological Survey Techniques of WaterResources Investigations, book 2, chap. E-2, p. 150.

Miles, C.E., and Whitfield, T.G., comps., 2001, Bedrock geology of Pennsylvania: Pennsylvania Geological Survey, 4th ser., dataset, scale 1:250,000.

Poth, C.W., 1963, Geology and hydrology of the Mercer Quadrangle, Mercer, Lawrence, and Butler Counties, Pennsylvania: Pennsylvania Topographic and Geologic Survey Water Resources Report 16, 149 p.

Rider, M., and Kennedy, M., 2011, The geological interpretation of well logs ( $3 \mathrm{~d}$ ed.): Glasgow, Bell and Bain, Rider-French Consulting Limited, 432 p.

Risser, D.W., Williams, J.H., Hand, K.L., Behr, Rose-Anna, and Markowski, A.K., 2013, Geohydrologic and water-quality characterization of a fractured-bedrock test hole in an area of Marcellus Shale gas development, Bradford County, Pennsylvania: Pennsylvania Geological Survey, 4th ser., Open-File Miscellaneous Report OFMI 13-01.0, 48 p.

U.S. Geological Survey, 2014, Hill shade base map and National Hydrography Dataset: The National Map, accessed July 30, 2014, at http://nationalmap.gov/.

Wyrick, G.G., and Borchers, J.W., 1981, Hydrologic effects of stress-relief fracturing in an Appalachian Valley: U.S. Geological Survey Water-Supply Paper 2177, 51 p.

\section{Acknowledgments}

The project was funded in part by the Pennsylvania Department of Conservation and Natural Resources, Bureau of Topographic and Geologic Survey. Additional funding was provided by the U.S. Geological Survey Cooperative Water and Groundwater Resources Programs. The Pennsylvania Department of Environmental Protection, Office of Oil and Gas Management was instrumental in the development of the project and providing industry contacts. The authors gratefully acknowledge the cooperation and logistical support provided by Catalyst Energy, Inc., and IronCarey, LLC, who allowed access to the Deep Hollow 3460 oil-and-gas well site.

\section{For additional information, contact:}

Director, Pennsylvania Water Science Center U.S. Geological Survey 215 Limekiln Road New Cumberland, PA 17070

Home Page: http://pa.water.usgs.gov/ 